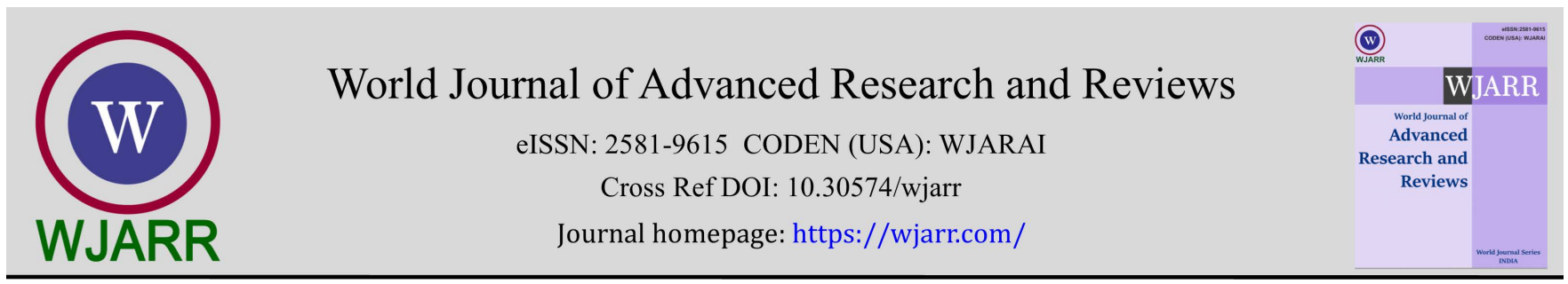

(REVIEW ARTICLE)

Check for updates

\title{
A study on growing Indian Economy in relation to the International Foreign trade
}

\author{
Dr Sumanta Bhattacharya ${ }^{1, *}$ and Bhavneet Kaur Sachdev ${ }^{2}$ \\ ${ }^{1}$ MAKAUT, Public-Foreign-Defence Policy, MPI(oxford University) ORCID ID : 0000-0003-2563-2787. \\ ${ }_{2}^{2}$ Political Science hons (Calcutta University,ORCID ID : 0000-0001-9156-0086.
}

World Journal of Advanced Research and Reviews, 2021, 12(03), 114-118

Publication history: Received on 17 October 2021; revised on 03 December 2021; accepted on 05 December 2021

Article DOI: https://doi.org/10.30574/wjarr.2021.12.3.0992

\begin{abstract}
India is transforming its economy, there is infrastructure development, introduction of technology into majority of the sector. India is adopting smart technology and smart sustainable living to become self sufficient with the aim to reduce imports and promote exports in foreign trade. The country has allowed $100 \%$ FDI in a number of sectors. India is becoming an manufacturing hub with the made in India scheme being implemented in every sector from agricultural to Industrial to Service Sector. Foreign trade promotes diplomatic relation between countries. India is the largest producer of many products in the world, the defence sector has also started their own manufacturing in India, the sector has exported many missile and aircrafts adding to the GDP growth. Made in India scheme has provided employment to the young youth and many other skilled and unskilled people..The 2021 to 2026 foreign trade policy focus on small scale industries -MSME who are contributing 40\% to the GDP growth and provided employment to maximum number of people after agricultural sector.
\end{abstract}

Keywords: Foreign trade; MSME; Small scale industry; GDP; Export; Import; Self sufficient

\section{Introduction}

International trade has a long history carried outby all civilizations with other countries.The need for trading was important as every country couldn't produce all the resources, due to climate and weather patterns, all the countries had their own way of production. Dependent on the quality and requirement trade was on,during the early ages. International trade started with the Barter system which was taken over by the Mercantilism during the $16^{\text {th }}$ and $17^{\text {th }}$ century. Liberalism started during the $18^{\text {th }}$ century, it was Adam Smith who spoke about International trade and wrote about the importance of specialization of production. The international trade started in the $19^{\text {th }}$ century where many discussion where held on the tariff system. However the world war I changed the scenario and the course of world trade, countries developed walls and they was restricted international trade among countries. 1927 saw the first world Economic conference organization by League of nations, the meeting was attended by all the developed Industrial countries which gradually formed the Multilateral trade Agreement which was later led to the Genera Agreement of Tariffs and Trade in 1947. The second world war also affected the International trade market. After world war II the advanced democracies led by US came up with a policy of removing barriers to International trade, with the view that free trade would not only bring prosperity but also promote world peace. In the first half of the 1990s, several major free trade agreements were negotiated some notable were North America Free Trade Agreement between US, Canada and Mexico which approved in 1993 and the Uruguay round agreement which finally ed to the establishment of World Trade Organization in 1994. Trade policy differs from country to country depending upon their per capita income, the most advanced and developed countries are in Europe, US and Japan where the per capita income is more than dollar 40,000 per year. Majority of the population live in the developing countries where the economic is poorly developed. For 30 years after the world was II, trade policies in many developing countries believed that in order to develop their

* Corresponding author: Dr Sumanta Bhattacharya

MAKAUT, Public-Foreign-Defence Policy, MPI (oxford University) ORCID ID: 0000-0003-2563-2787.

Copyright $(2021$ Author(s) retain the copyright of this article. This article is published under the terms of the Creative Commons Attribution Liscense 4.0. 
economy, the creation of manufacturing sector as necessary which would enhance the domestic economy and the strategy is referred to as import substituting Industrialization However this didn't last for long with advancement of technology and globalization every country is trying to become self -sufficiency, however due to certain factors the trade industry is going and there is no reduction in the export business. India from 1947 to 1991 was a closed economy, there were huge imports and tariff on the items. However 1991, economical reforms in India took place, it brought an end to British Raj system and opened doors for liberalization, privatization and globalization FDI started in India, which equally gave rise to foreign trade in India which has played a significant role in the development of economy.

\subsection{Research Methodology}

For the purpose of this exploration, I have used a amalgamation of two of the archetypical social sciences research tools application -as they are authentic and brilliant method to assemble statistics from multiple appellant in an methodical and convenient way. Question were asked to the common youth, public policy Analyst, Businessmen, International relation students, foreign affairs, researcher. Interviews -consisting of several interrogation which were dispersed among representative of each contender group.

\section{Objective of the Research Paper}

The main areas of exploration in this paper incorporates

- Why is foreign trade important.

- How has foreign trade contributed to the economy development of India.

- What is the future of foreign trade policy of India with emphasis on Made in India scheme.

\section{Literature Review}

Foreign trade has played an important role in the growth of Indian economy, It helps to produce goods and service less and at a cheaper price as a result the cost of production in manufacturing becomes less, second foreign trade escalates the scope of market due to the high domestic demand and foreign demand of a commodity which results in mass production where the average cost reduces and the price of goods also reduces. It help to get access to a varieties of good both in quality and quantities terms. Above all it helps in economy development the iron and steel industry in India requires import of technical knowledge from other countries to establish the Industry. Without foreign trade it is not possible to fulfill the demand of the growing population, there is scarcity of consumers goods due to climate change and natural calamities due to import from foreign countries India is able to keep people stable with good and services. For instance during the COVID-19 time, the ongoing second wave, oxygen cylinder, mask and testing kit have come from foreign countries. Foreign trade today has become a significant part of government policies, where the country is trying to reduce its import and maximize it export from which the government has introduced made in India products, aiming to make India a manufacturing hub. Foreign trade is also a tool to maintain diplomatic relations with other countries. India has both surplus trade balance and negative trade balance which is very much seen in the case of China where China imports to India are much more than the Exports. Moreover the bilateral relation between China and India is affected their foreign trade relation. India also has the largest trade deficit with China. India is highly dependent on the product from China. As per 2017-18 India has a negative trade balance with Iraq, South Korea, China, Switzerland, Saudi Arabia, where as it has a surplus trade balance with America, Bangladesh, Nepal, UAE and UK. The government has initiated to make India a friendly location for manufacturing good, the foreign policy from 2015 to 2020 has focused on escalating its export of commodities and increasing employment with the vision of Made in India, the government is making its own defense equipment, submarine and aircrafts and they have been successful in exporting to countries like Maldives, Philippines and made others which has increased their GDP growth. Branding companies are planning to exodus export in sectors, in India's traditional sector, FTP would reduce by $25 \%$ which will enhance the domestic manufacturing and export. Moreover India has made a significant engagement in the world trade of $2020 . I t$ as the 2015 foreign trade policy which introduced the Merchandise Export from India Scheme(MEIS) to export specific commodities to specific markets Services Export from India scheme(SEIS) for incrementing exports of major services.

\section{Findings}

7500 commodities are exported from India to 190 countries where as India imports 6000 commodities from 140 countries. Services has become a major part of import and export The top export items of India are petroleum products, drug formulation, precious stones, gold, metal Jewellery, Iron and steel, organic chemical, Marin products, RMG cotton including accessories, Motor vehicles, electric machinery and equipment, Agricultural products, floriculture. The main countries whom India export are USA, China, Hongkong, Singapore, UAE, Netherlands, Germany, Bangladesh and Nepal. 
Service would include software services which is 40 to $45 \%$,business is $18-20 \%$, travel includes 11 to $14 \%$ and transportation is about 9 to $11 \%$.

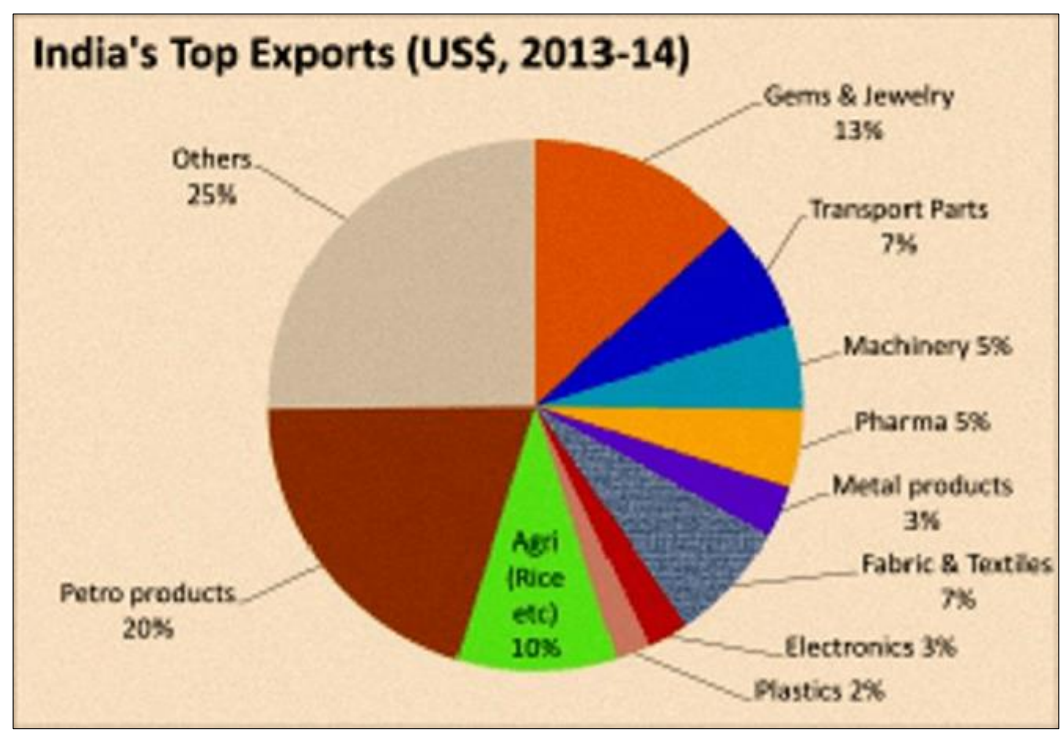

Figure 1 India's Top Export products

When it comes to import commodities the main items are petroleum- crude oil, Gold, Coal, coke and briquettes, Telecom instruments, organic chemicals, Industrial machinery for Dairy etc, electronic components, pearl, precious, semiprecious stones, Iron and Steel. Major countries import are China, Switzerland, Iraq, Singapore, Indonesia, Korea RP, Saudi Arabia, USA, UAE. The foreign trade accounted to $48.8 \%$ of the GDP for the year 2018, it was 31.5\% for the year 2019 and for 2020 it stood at $27.8 \%$.

Table 1 A study on the imports and exports in India since the time of liberalization

\begin{tabular}{|c|c|c|c|}
\hline Year & Import & Export & Trade Deficit \\
\hline 2000 & 60.8 & 43.1 & 17.7 \\
\hline 2001 & 54.5 & 42.5 & 12.0 \\
\hline 2002 & 53.8 & 44.5 & 9.3 \\
\hline 2003 & 61.6 & 48.3 & 13.3 \\
\hline 2004 & 74.15 & 57.24 & 16.91 \\
\hline 2005 & 89.33 & 69.18 & 20.15 \\
\hline 2006 & 113.1 & 76.23 & 36.87 \\
\hline 2007 & 100.9 & 112.0 & 11.1 \\
\hline 2008 & 305.5 & 176.4 & 129.1 \\
\hline 2009 & 274.3 & 168.2 & 106.1 \\
\hline 2010 & 327.0 & 201.1 & 125.9 \\
\hline 2011 & 461.4 & 299.4 & 162.0 \\
\hline 2012 & 500.4 & 298.4 & 202.0 \\
\hline 2013 & 467.5 & 313.2 & 154.3 \\
\hline 2014 & 462.9 & 318.2 & 144.7 \\
\hline 2015 & 447.9 & 310.3 & 137.6 \\
\hline 2016 & 381 & 262.3 & 118.7 \\
\hline 2017 & 348.3 & 275.8 & 108.5 \\
\hline 2018 & 465.58 & 303.52 & 162.05 \\
\hline 2019 & 514.07 & 330.07 & 184 \\
\hline
\end{tabular}


India's GDP stood at 195.86 Lakh crore in FY21.,the per capita income at current price is 127,768 rupees in FY21. India's trade and external sector has a contribution to the GDP growth and expansion per capita. The export rate from April 2020 to February 2021 stood at 439.64 billion dollar and imports was 447.44 billion dollar, Foreign trade falls under the Ministry of Commerce and Industry, the government is trying to grow his export market and provide employment to more and more educated people, young youth and unskilled and semi-skilled workforce. As per March 2021 the Indian foreign exchange stands at 582.04 billion dollar.

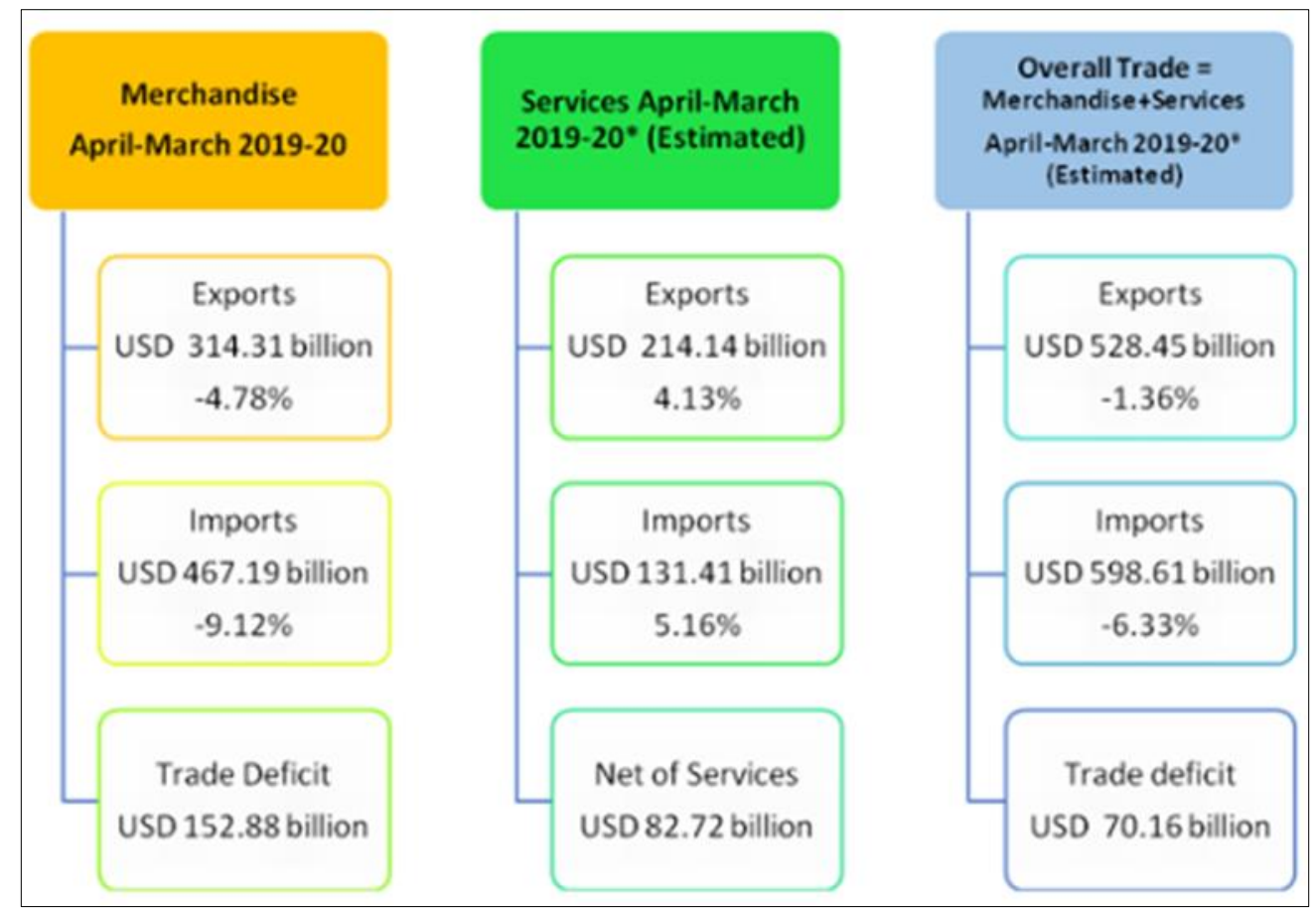

Figure 2 International Trade Policy and FDI import and export trade during the Pandemic period

The agricultural and Processed food products export development authority introduced its first virtual trade fair to boost the export of agricultural and processed food products in India. The Foreign trade policy from 2021-2016 motive is to focus on MSME and enhance export business, it also aims to establish a mechanism to escalate import screening which will help domestic manufacturers to understand the market potential and with policy also aims to encourage ecommerce exports and identity new areas to boost domestic exports.

India is one of the leading players in the global market,its government reforms and trade policy has made it stand, at the $3^{\text {rd }}$ position for foreign investment. The advancement in technology and infrastructure development has opened door for better economic and trade in the upcoming years. Japan, Australia and China have incremented their contribution towards economic development and growth in the global market.

\section{Way Forward}

Foreign trade has improved the industrial sector and aided to the development of economy. India's made in India scheme is gaining momentum has they have reducing their imports in all sectors from agricultural to Industrial to defense, Made in India manufacturing has started. In order to cut down their imports from China, India has opened its own Samsung manufacturing factor in Nodia. Vertical farming and smart farming is being adopted in India which will cut don the imports and increase the export as India is the largest and second largest producer of maximum agricultural products and provides raw material for Textile Industry. Textile Industry is the oldest Industry has exports maximum of its product including cotton. India's population is expanding and so will be the demand in the upcoming years. India is home to maximum youth population, the Made in India scheme will employ more youth, with small scale Industries has provided employment to maximum number of people after the agricultural sector. India's foreign trade will add to the GDP will growing demand for ayurvedic medicine and increasing producing in India, the MSME are contributing to the export market by $40 \%$. India aim to become self -sufficient through Made in India scheme will have a gigantic impact on the foreign trade with reducing in imports and increment in Exports. 


\section{Conclusion}

Over the years the foreign trade has played a remarkable role in uplifting the economy of India, it was in 1991 which allowed foreign investment in India, today India is among the top third countries for foreign investment country which has maximize employment rate in India, along with domestic market has grown, Foreign trade have provided ample support to India's economy development. India new scheme Made in India, aims tor reduce its import rate with infrastructure development, domestic manufacturing and bring in new technology and smart planning to double its producing rate, making India self -reliant, which will bring massive per capita income and contribute to the GDP.

\section{Compliance with ethical standards}

\section{Acknowledgments}

Timir Baran Chatterjee: B.com(H), M.com, FCS, ACMA, MBA Manager Partner at Tax Connect Advisory Services LLP Chairman, IDT Chairman, Bengal chamber of commerce and Industry.

\section{Disclosure of conflict of interest}

The authors hold no conflict of Interest.

\section{References}

[1] Vinay Kumar. An analysis of Growth of MSMEs in India and their contribution in employment and GDP of the country. 2017.

[2] Anna K Patil. Role of small scale Industries in economic development, Research Gate. 2011.

[3] Foreign Trade policy 2021-2026: Expectations for the import-export sector. 2021.

[4] Govindan P. A study on growth and impacts on India's foreign trade-an engine for entrepreneurship and economic development ReseachGate. 2020.

[5] Shuchi Gupta. An analysis of Indian Foreign Trade in Present Era. 2019.

[6] Govindan P. A Study on Growth and Impacts of India's Foreign Trade -An Engine for entrepreneurship and economic development, Applied Economics and International Development. 2020; 20(2).

[7] Rajesh K Pillania. An Exploratory study of Indian Foreign Trade, Journal of Applied Economic Sciences. 2003; $3(5)$.

[8] S Gupta. An analysis of Indian Foreign Trade in Present Era, SSRN. 2020.

[9] Singh R, Singh S. The Policy and Operational Challenges in Formulating India's New Foreign Trade Policy, ORF. 2021.

[10] S Sabade. India's Foreign Trade and Socio-Economic Development (Trio of ETO Compliance, Currency Depreciation and Global Crisis, ScienceDirect.

\section{Author's Short Biography}

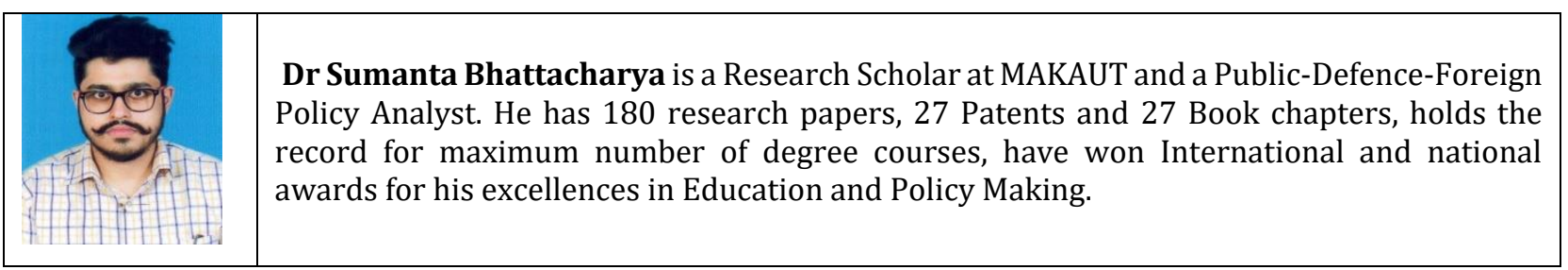

